UDC 316.776 .33

DOI: $10.21668 /$ health.risk/2018.2.16.eng

\title{
HEALTH COMMUNICATION: THEORETICAL AND PRACTICAL ASPECTS
}

\author{
M.A. Grishina
}

State Academic University for the Humanities, 26 Maronovskii lane, Moscow, 119049, Russian Federation

Nowadays chronic non-infectious diseases are spreading rapidly and health risk factors related to people's behavior are becoming more and more significant. Efficient communication between medical personnel and their patients is one of the basic ways to stimulate self-preserving behavior. The paper dwells on health communication phenomenon and basic theoretical approaches which allow to get an insight into the essence of the process. Communication is studied at interpersonal, group, organization, and mass levels.

As information technologies now play a significant role in the life of any society, the author considers certain possibilities of their application in public health care, for example, in such spheres as electronic and mobile health care, or telemedicine, and also analyzes experience accumulated in application of communication programs both in the RF and abroad. Special attention is paid to analyzing how efficient communication programs are, and how they can possibly influence population knowledge, attitudes, and behavior as regards their health. Behavior changing models give theoretical grounds for changes in people's behavior; such models are "a model of belief in health" (I. Rosenstock, D. Becker), "theory of planned behavior" (I. Ajzen), theory of stage changes on behavior (G. Prochask). The paper also contains analysis of possibilities to conduct sociological research when working out, implementing, and assessing communication programs aimed at formation of healthpreserving behavior. To efficiently implement communication programs, it is necessary to combine efforts by medical experts and experts in social and humanitarian sciences.

The paper can be of interest to a wide range of readers, especially to those who specialize in prevention medicine and sociology of health.

Key words: communication, communication programs, electronic health care, mobile health care, health, sanitary education, chronic diseases, health-preserving behavior, changes in behavior.

Population health is a complicated phenomenon which is determined by a set of biological, social, political, economic, and other factors. In the middle of the 20th century, morbidity structure changed drastically both in developed and developing countries. Non-infectious chronic diseases, such as cardiovascular and oncologic ones, mental disorders etc., started to prevail. According to the data provided by Rosstat [1] the most widely spread death causes in the RF in 2016 were the following: cardiovascular system diseases $(57.4 \%$, including primary hypertension and increased blood pressure, which accounted for $21.9 \%$ ) and malignant neoplasms (19\%). Therefore, it is vital to examine risk factors which cause occurrence of such pathologies.

Prevalence of chronic noninfectious diseases results from ecology, political and economic situation in the country, public healthcare functioning as a social institution, as well as behavioral patterns which people have in relation to their health.

The World Health Organization

(C) Grishina M.A., 2018

Marina A. Grishina - post-graduate student at Sociology Faculty (e-mail: mgrishina730@gmail.com; tel.: +7 (929) 541-21-77). 
spots out three basic criteria which allow to attribute this or that factor to a group of factors which stimulates occurrence or makes for spreading of priority noninfectious chronic diseases. These criteria are: considerable prevalence of a factor in most countries; a scientifically proved correlation between a factor and a disease occurrence; lower risk of such diseases when risk factors are under control. According to the WHO data, risk factors are: increased blood pressure, excessive body weight, increased cholesterol and dextrose contents in blood, alcohol intake, smoking, unhealthy nutrition, and insufficient physical activity [2].

Control over chronic non-infectious diseases is one of priority tasks set in most countries in the world, including the Russian Federation. The state program for public healthcare development adopted for the period up to 2025 includes the following: "giving up smoking, drugs, and alcohol abuse, provision of conditions for healthy lifestyle, correction, and regular control over behavioral and biological risk factors of non-infectious diseases at population, group, and individual levels should become the most important component in the health preservation policy" ${ }^{1}$.

There are some goevrnmental measures which help to gain control over chronic diseases prevalence:

- legislative ones which are aimed at adopting laws protecting public health, for example, a law which forbids smoking in public places;

- economic ones which are related to public healthcare funding and provision of qualitative medical and sanitary aid;
- control over production and distribution of consumer goods, first of all, food products, which include limitation imposed on production and distribution of unsafe products, for example, food stuffs which contain trans fats, synthetic preservatives and dyes etc.;

- information and communicative ones which are aimed at creating greater population awareness about possible health risk factors and changes in behavioral patterns.

There is a term "health communication" which is now established in scientific literature written in English. This term can either mean "communication about health" or "communication in the sphere related to health". Communication about health can be defined as a "scientific sphere and practices how to apply communicative strategies in order to provide information and influence decision-making which can improve health both at individual level and in the whole society" [3]. There are two basic trends within this sphere of knowledge. The first one involves theoretical insights into communication about health, analyzes communication process peculiarities, and is based on theoretical developments in communication science. The second trend is primarily oriented at considering communication as a practical activity aimed at promoting healthy lifestyle to population. Thus, to define this trend, we can apply such terms as "health promotion", or medical (sanitary) education which can include all the activities "related to informing, educating, or consulting aimed at creating such a lifestyle which promotes health preservation" [4].

\footnotetext{
${ }^{1}$ Razvitie zdravookhraneniya: Gosudarstvennaya programma Rossiiskoi Federatsii / utv. Postanovleniem Pravitel'stva Rossiiskoi Federatsii № 1640 ot 26 dekabrya 2017 g. [Public healthcare development: The RF State program / approved by the RF Governmental Order on December 26, 2017 No. 1640]. Ministerstvo zdravookhraneniya Rossiiskoi Federatsii: ofitsial'nyi sait. Available at: https://www.rosminzdrav.ru/ministry/programms/health/info (06.06.2018) (in Russian).
} 
Communication in the sphere related to health started to institutionalize as a scientific branch in 80-90ties last century in the USA, when such American experts as B. Korsch, D.Cassata, T. Costello, T. Thompson and others published their first works on the subject. "Health Communication" journal has been regularly published since 1989; and "Journal of Health Communication: International Perspectives", another periodical edition, was first issued in 1996. The Department for Communication in the sphere related to health became an essential part of the International Association for Media and Communication Research in 1985; this Association unites experts in the field. Nowadays, a number of the US higher educational establishments in such states as California, Massachusetts, North Carolina, Oregon, and others, train experts in communication in the sphere related to health [5]. This scientific branch was recognized as such in Europe a bit later, in early 2000ties. The European Association for Communication in Public Healthcare was established in 2001, and some specialized structures were created to train experts in European universities in the Netherlands, Great Britain, Switzerland, and Denmark. "Communication \& Medicine", periodical scientific edition, was first published in Great Britain in 2011.

Unfortunately, we can't speak about this scientific branch being institutionalized in Russia as a specific knowledge sphere. But still, there are a lot of scientific works in the field; here we can mention papers published by E.V. Dmitrieva, I.V. Yakovleva, K.V. Kuz'mina, E.V Semyonova. Theoretical and practical research on "risk communications in the sphere related to health" is described in works by N.A. Lebedeva-Nesevrya and A.O.Barg who consider "risk communications in the sphere related to health as a specific type of risk communications due to essential peculiarities of health risk itself" [6]. The authors draw attention to health risks being perceived in the society as the most significant ones as they are related to basic human needs and affect interests of most people.

When we consider communication as a scientific branch we should rely on theoretical developments in the sphere of communication. Thus, A.S. Babrow and M. Mattson suggest to apply a classification developed by R. Craig to get an insight into a phenomenon of communication in public healthcare sphere. R. Craig outlines seven paradigms: rhetorical, semiotic, phenomenological, cybernetic, psychosocial, socio-cultural, and critical one [7]. Within the rhetorical paradigm, communication is considered as a practical activity which has to persuade. This paradigm can be applied to examine persuasive influence exerted by social communication in public healthcare sphere.

Semiotic paradigm analyzes communication as interaction mediated with various symbols and signs; this interaction is aimed at creating mutual understanding between those who participate in communication. This approach can be applied in communication about health: it is meanings that determine people's attitudes, values and actions concerning their health. T. Caughlin examined possibilities to apply semiotic approaches to construct an ideal identity, a human body.

Within phenomenological paradigm, communication is viewed mostly as a dialogue, as one person surviving experiences of another. This approach can be applied to explain health as a specific being of a person in the world. In real life it means that there should be trust between a doctor and a patient, and communication skills are to be developed. 
Cybernetic paradigm for communication was created by Norbert Wiener; in his opinion, " the whole sphere of management and communicative theory, concerning both mechanisms or animals, can be called cybernetics" [8]. It means that information is transferred from one subject to other, and this process underlies communication; this information transferring is based on coding/decoding. As regards communication about health, such subjects are medical experts and patients.

Psychosocial paradigm considers communication as a process involving people's interaction and their mutual influence on each other; this process is determined by psychological factors. This approach is widely used to analyze communication about health. Barbrew and Mattson think that when a patient interprets information given to him by a doctor, he or she "not only obtains and carefully processes this information but also tries to develop understanding of health within the context of related convictions and values which underlie his or her personality; his or her social role; relationships with medical experts, family, and other people" [7].

Socio-cultural paradigm explains how social order is reproduced via communication, and what peculiarities occur in communication due to influences exerted by a society. Thus, communication about health is determined by a set of social, cultural, religious, and other factors.

Critical paradigm is closely related to Frankfurt school. If we take public healthcare, this approach can be applied to analyze how policies can set and even impose certain behavioral standards, notably, in public healthcare sphere.

Therefore, all the above-mentioned paradigms can serve as theoretical grounds for communication about health.
Communication in the sphere related to health can be considered at different levels. K.V, Kuz'min and E.V. Semyonova [9] describe four basic communication types: interpersonal, group, organizational, and social (mass) one. Interpersonal communication is a basic level; for example, interaction between a doctor and a patient. Such communication can be both onesided and two-sided. For example, within T. Parsons' structural functionalism, such communication can be viewed as a oneside process when a doctor gives orders, and a patient has to obey them. Two-sided communication means there is information exchange between a doctor and a patient, as well as a possibility to refuse following doctor's prescriptions (an informative consent model). According to I.B. Nazarova, "relationships between a doctor and a patient in Russia are definitely paternalistic based on two sides being unequal in treatment and diagnostics" [10]. Then, the next level is group communication which means interaction with this or that social group, for example, a group of drug addicts. Organizational communication means interaction between various components in public healthcare structure. Mass communication is one of the most widely spread types of communication about health and is mostly realized via mass media, such as $\mathrm{TV}$, radio, the Internet, etc.

Nowadays, as information technologies are playing more and more significant role is our life, such a phenomenon as "electronic public healthcare" occurs. It involves application of electronic case histories, mobile public healthcare, social networks, telemedicine, etc. The report titled "From innovations to implementation: Electronic healthcare in Europe" issued by the WHO states that such programs "make for wider range of services provided for population and involvement of population 
groups who were hard to reach earlier, help to overcome geographical barriers and reach new levels of economic efficiency in provision of medical services" [11]. The WHO research which was performed in 2015 revealed that $84 \%$ of the WHO member states had their national policy related to providing healthcare services to population, and $74 \%$ of them applied electronic healthcare and information technologies when implementing this policy [11]. Application of IT in medicine is becoming more and more popular among experts in Russia [12]. "A physician and Information Technologies" periodical edition has been published in our country since 2004. Such specialized societies as Association for Medical Information Technologies Development and the Russian Association for Telemedicine operate in Russia.

American and Western European experts in sociology of health have developed a lot of various communication models. Some of them were thoroughly analyzed by E.V. Dmitrieva, a Russian sociologist [13]. There is a therapeutic model which focuses on relationships between a doctor and a patient. According to $\mathrm{T}$. Brewin [14], basic tasks a doctor has to perform in this approach is informing a patient and readiness to provide psychological support to him or her. "A concept of health" model developed by I.Rosentock includes "such components as individual concepts about susceptibility to a disease, on how grave a diseases is, what are the advantages of preventive behavior, and what prevents a patient from pursuing such behavior" [13]. These concepts are determined by social, psychological, demographic, and other factors which can be analyzed; this analysis will help to assess influence exerted by communication programs in the sphere of public health on a person's behavior. Interaction model de- veloped by I. King also focuses on interaction between a doctor and a patient, however, greater attention is paid to interpersonal relations.

A model of communication about health developed by L. Northoust and P. Northoust describes interactions between medical staff (doctors, nurses, social workers, and pharmacists), patients, and "significant others" (family members, colleagues, and friends). This model also considers context, that is, an environment which communication process takes place in. "In the narrow sense, we speak here about hospitals, polyclinics, and other medical organizations; about conditions in which doctors meet their patients (a size of a room, foreign objects being found in it, privacy, etc.). In the wider sense, we speak about attitudes of individuals or groups of people to their health, medical organizations, etc." [13].

Communication context can be considered most profoundly and include various aspects. I.V. Yakovleva [15] highlights several contexts of communication. First, intrapersonal context, which includes a person's knowledge, values, and attitudes. This context enters communication and obtains information about health. Secondly, there is interpersonal communication which implies mutual relationships between all the subjects in communication. Third, there is an organizational aspect related to medical organizations functioning, possibilities and ways to organize communication processes. Fourth, there is crosscultural aspect of communication which allows to analyze how significant culture is in development of people's ideas on health and diseases as well as to explain crosscultural differences which occur in interactions between doctors and patients in a particular country. The fifth communication context is a social one, and mass media, the 
sixth. We should examine their technological capabilities as well as their ability to influence a person's behavior related to his or her health.

A Kleynmann's explanation model is the next to discuss. This model includes five components: "etiology, a set of symptoms, pathophysiology, clinical course, and treatment" [12]. Interactions between a doctor and a patient, or between a patient and his or her family are examined in this model as communication between different explanation schemes and cognitive systems. These systems can either interact in harmony, or enter a conflict. Thus, for example, the same physiological state can be seen by a doctor and a patient in a different way: patients wait not only treatment from their doctors, but also relevant explanation, or interpretation of various actions and manipulations. To sum up, there are a lot of communication models which can give grounds for analyzing communicative process in healthcare.

N.A. Lebedeva-Nesevrya $[16,17]$ thoroughly analyzes subjects who participate in communication process about health risks in her works; she spots out 5 basic subjects [16]. The most significant subjects are experts in health risk assessment representing such expert societies as Rospotrabnadzor, medical experts, and scientists. Their basic task is to detect occurring risks and to analyze how to minimize them. Another significant subject in risk communication is population represented by various social groups susceptible to various risks. The third subject in risk communication is represented by mass media which can play either a positive role making for health risk reduction or, on the contrary, provide certain information which only causes new risks to arise. The fourth subject is authorities who are responsible for decision-making in the sphere of risk communication implementation. The fifth subject can be various non-commercial public organizations, their basic task being implementation of programs aimed at stimulating changes in people's behavior. Interaction between all the above mentioned subjects creates a complicated system of health risk communication which can either help to detect and reduce health risks or, on the contrary, be rather dysfunctional.

Communication as a practical activity is realized via specific communication programs. The latter can focus on population as a whole or on specific social groups. let us consider some examples showing how communication in the sphere of public health is realized in Russia and abroad. There is a complex program, called "Healthy people" which has been existing in the US since 2010; this program was created to provide efficient communication in public health sphere. In order to analyze communication practices in the sphere, a whole set of parameters was created; they were people's access to the Internet; websites related to health issues; health literacy of population; communications between a doctor and a patient; communication campaigns; etc.

According to research results [18], medical literacy depends on a race and ethnic group as well as education. Thus, only $9 \%$ Whites had little medical knowledge while this figure amounted to $24 \%$ among Blacks; it was $23 \%$ among American Indians and Alaska population; and it was $41 \%$ among Spanish and Latin American population. poor awareness about healthy lifestyle prevailed among people with education lower than secondary $(54 \%)$. This parameter amounted to $15 \%$ among secondary school graduates, and only $5 \%$, among those who graduated from a higher educational establishment. 
The research also contains some data on peculiarities which occur in communication between a doctor and a patient. Thus, $65 \%$ respondents stated doctors listened to them attentively during their visit and showed respect; $66 \%$ told doctors managed to provide them with information which was easily understood; $53 \%$ claimed doctors spared them enough time.

The Internet became accessible to significantly greater number of people in the US from 2000 to 2010: a share of people older than 18 who had access to it and actively used it grew by $165.4 \%$. A quantity of web-sites which provided information about health also increased greatly. Thus, for example, a number of sites with a possibility to get a feedback grew from $59 \%$ to $88 \%$ over 2006-2009.

The research also revealed that $80 \%$ campaigns performed formative research; $68 \%$ had a monitoring system which they applied in their programs; and 645 analyzed the results [18].

So, communication about health is an essential part of the US public healthcare system and is supported by the state itself. This system is implemented via multiple communication campaigns which are aimed at maintaining population health. Thus, the Centers for Diseases Control and Prevention in the US held the following campaigns [19]: 1) HIV/AIDS prevention, "HIV Treatment Works", "Act Against AIDS"; 2) against tobacco smoking, "Tips From Former Smokers"; 3) a campaign with its goal being an increase in population's physical activity; 4) osteoporosis prevention, "Nutrition for Everyone: Calcium and Bone Health"; 5) oncologic dis- eases prevention, "Inside Knowledge: Get the Facts About Gynecologic Cancer Campaign", and some others.

Some programs and projects aimed at creating healthy lifestyle of the population are planned to be implemented in the RF by state authorities. Thus, "Healthy lifestyle creation passport" ${ }^{2}$, was approved on July 26, 2017; the basic idea here is to increase a share of people who pursue healthy lifestyle from $50 \%$ by 2020 and to $60 \%$ by 2025 ; this share is assumed to grow due to more people taking on responsibility for their own health. This project goals are to reduce tobacco smoking and alcohol intake, and to stimulate people do more exercises and sports. It includes an information campaign aimed at creating self-preserving behavior towards one's health, especially, when it comes to reproductive health. The campaign is to be held in the media and social networks via micro-targeting.

The RF Public Healthcare Ministry stimulated creation of "Healthy Russia" portal in the Internet dedicated to healthy lifestyle; there is a hot line functioning on it, and it contains reference information on healthy nutrition, and on ways how to give up tobacco smoking and drugs taking.

Various prevention programs are also implemented by medical and educational establishments in the RF regions; they are, for example, "Healthy generation", "It's cool to be healthy", "My choice", "All colors except black", and a lot of others.

Domestic experts perform research aimed at detecting and assessing population health risks. Thus, in 2013-2014 in Perm region Rospotrebnadzor's Federal

\footnotetext{
${ }^{2}$ Pasport prioritetnogo proekta «Formirovanie zdorovogo obraza zhizni» / utv. Prezidiumom Soveta pri Prezidente RF po strategicheskomu razvitiyu i prioritetnym proektam, protokol № 8 ot 26.07.2017 g. [Priority project passport "Healthy lifestyle creation" / approved by the Presidium of the RF President Council on Strategic Development and Priority projects, minutes dated July 26, 2017 N 8] // Konsul'tantPlyus. Available at: http://www.consultant.ru/document/cons doc LAW 222210/ (07.06.2018).
} 
Scientific Center for Medical and Preventive Health Risk Management Technologies questioned people employed at industrial enterprises as well as people who were employed in spheres not related to any industry. It helped to reveal basic population risks factors which existed in Perm region from the respondents' point of view [20]. The results revealed that both groups considered adverse ecological situation at a place where they lived to be one of the most significant risk factors $(68.8 \%)$; hazardous working conditions followed (54.9\%); smoking and alcohol abuse were mentioned by $48.5 \%$; and low quality food products, by $40.2 \%$. Therefore, awareness about risk factors can be considered quite high, but at the same time there is not enough information on how these factors influence people's health. We should also note that this information is not fully accepted and it becomes apparent when people continue to pursue behavior which is risky for their health.

Results of national monitoring over population health in Russia performed by the Russian Public Opinion Research Center in 2009-2017 [21] revealed that people considered stress and excessive work to be the most significant factor which cause diseases $(35 \%)$, as well as not having enough money to spend on diseases treatment and prevention (35\%). And here we can also state that the contribution made by the second factor has increased over the last 5 years, from $19 \%$ to $35 \%$. Such morbidity causing factors as adverse environment $(32 \%)$ and age $(32 \%)$ follow. So, people see a lot of outer causes, while at the same time they are not fully aware of risks related to nutrition, physical activity or bad habits.

There are public organizations which develop and implement communication programs among population. "Health and Development" Fund for Supporting National Projects in the sphere of public healthcare is one of them [22]. Its activities are aimed at implementation of free-ofcharge communication programs on the RF territory; for example, a program called "an SMS to a mom". Its goal is to provide pregnant women and women with infant children (under 1 year of age) with useful knowledge, to create correct attitudes in them, and to make them change their behavior. The program is supported by the RF Public Healthcare Ministry. There are other programs such as "We Are Giving Up Smoking": to promote abandoning this bad habit; "IVF School" which deals with issues arising when reproductive technologies are applied; "Everything That Concerns You" program motivates teenagers to pursue healthy lifestyle. Most of these programs are mobile and they allow to get information from SMS, messengers, mobile applications, social networks, etc.

Let us consider some data obtained during sociological research which was conducted within "An SMS to a mom" mobile communication program by E.V. Dmitrieva, S.A. Phrolov, and M.A. Grishina in 2013-2014. The research was performed as a questioning at V.I. Kulakov's Scientific Center for Obstetrics, Gynecology, and Perinatology, as well as a questioning in the Internet. 751 pregnant women and women with infant children (under 1 year of age) from $64 \mathrm{RF}$ regions took part in the program and received qualitative medical information on pregnancy and a child's development during its first year of life. The information was provided with SMS, at webinars, on a specialized website, and in social networks. Most of the women participating in the programs became mothers for the first time in their lives $(70 \%)$. 
Participants got the information about the program form the following sources: posters and leaflets in antenatal clinics $(37.8 \%)$, their doctors' recommendations $(23.5 \%)$, the Internet $(18.5 \%)$. The fact that almost one fourth of the questioned women obtained useful information from their doctors, that is, the program was recommended by medical staff (gynecologists), proves that communication process is a complex one.

Women's motivation to receive information from reliable sources, first of all, their appeal for a piece of advice to medical staff, is one of the basic indicators o the program. One fourth of respondents (24.9 $\%)$ in 2013 and one third (35.8\%) in 2014 stated that they asked their doctors to consult them on issues which were discussed in SMS. When asked if an SMS was a motive to search for additional information on a certain subject, most participants $(77 \%)$ gave positive answers. 9 out of 10 participants claim their follow recommendations received via SMS in their everyday life. When we examine actual behavior of subscribers we can see that pregnant women took vitamins regularly (76.8\%); in 2013 each third woman was physically active (30.4\%), but in 2014 each second (48.5 $\%)$. A bit more than a half women practiced breastfeeding. Most women (84.2\%) vaccinated their children in full conformity with the vaccination schedule approved in the country. Pregnant participants noted they obtained a lot of vital and useful information on the following: 1) healthy nutrition $(77.5 \%) ; 2)$ data on welfare and benefits $(69.3 \%)$; 3 ) emotional state during pregnancy $(67.3 \%)$. Mothers with infant children (under 1 year of age) stated the most useful information included the following 1) information about a newborn health $(91.4 \%)$; 2) key stages in a child's development during its first year of life; 3 ) information about a mother's health after childbirth (80.4\%); 4) vaccination (79.3 $\%$ ). Most participants gave positive feedback about the program (85.9\%); $77.9 \%$ recommended it to their friends and acquaintances. About $82 \%$ subscribers kept SMS with useful information in their phones so that they would be available in case of necessity. Given all the abovementioned, we can state that any communication programs when it is implemented should be followed with estimations and analysis of influence it had on a target audience. It corresponds to basic principles of the World Health Organization (WHO).

From the WHO point of view [23], there are several significant aspects which should be taken into account when such programs and communicative influences are implemented among population. First of all, it is very important to remember that a program should be implemented within a specific context which, on an individual level, is determined by accumulated experience, knowledge and beliefs of a person, and at a society level, by existing social standards, cultural and religious traditions. Secondly, one should always bear in mind that there can be a discrepancy between planned and actual effects which occur due to a program. It can be caused by possible differences in information perception by those who receive and decode it, as well as by absence of preliminary testing and examining how information provided by a program is perceived by a target audience. The third significant aspect here is understanding that communication is a two-side process, and a key task of such programs is to perform assessment research, that is, to assess audience needs, to perform formative assessment, monitoring, and to assess influence exerted by a program with help of sociologists and experts in the sphere of healthcare. Communication in the sphere 
related to health requires a lot of sociological research, as it is various qualitative and quantitative sociological techniques that can help us to develop communication programs and to assess their effects correctly. Quantitative sociological techniques (questioning, content-analysis, etc.) allow to estimate prevalence of diseases, bad habits, and how committed people are to various self-preserving behavioral attitudes. Qualitative sociological techniques (depth interviews, focus groups, etc.) help to reveal peculiarities related to interpretation of obtained information, cultural aspects, and other specific features of various target groups.

D.V. Vizgalov thinks that a key peculiarity of qualitative techniques applied in programs assessment is a task "to understand how examined people or groups perceive existing processes, their behavior, and conditions" [24]. Sociological research can enlighten on target audience needs; existing gaps in people's knowledge and problems related to their behavior; how information provided by a program is perceived; whether a language applied is easy to understand; whether an information channel is a convenient one; on planned results of a program effects on people's knowledge, attitudes, and behavior. As a rule, such research is based on theories which describe changes in behavior.

The theory of planned behavior developed by I.Ajzen [25] is one of the most well-known theories which describe changes in behavior. This theory explains changes in behavior making it more favorable by a person's intention. However, this intention, in its turn, depends on three factors: "attitudes towards a new behavioral model (a person is sure a result will be positive); subjective standards (including social ones, for example, negative attitudes towards smoking); inner or outer control over behavior" [8]. This model often serves as theoretical grounds for implementation of communication programs aimed at changes in behavior.

Another theory is a cognitive one which represents "a model of belief in health" developed by I. Rosenstock and D. Becker. According to this theory a person's behavior is determined by his or her beliefs as regards existing health risks. As $R$. Nisbeth states, "in order to change their behavior, people should feel there is a personal threat to their health; they should consider possible consequences to be serious; and they should see that certain actions which they take can possibly reduce or even eliminate risks completely" [26]. The theory of stage changes in behavior developed by J. Prochaska and K. DiClemente states that changes in behavior occur in certain stages. The researchers spot out 5 following stages of changes in behavior: 1) unawareness when a person doesn't intend to change his or her behavior in the nearest future; 2) awareness when a person gets to know a certain problem exists; 3 ) intention, a person is ready to take an action; 4) an action itself when behavior changes; and 5) commitment, keeping one's behavior within these new frameworks [26]. Such domestic researchers as Yu.P. Averina and E.V. Dmitrieva adapted this theory and now use it in their work. In their opinion, efficiency of a communication program can be analyzed with 3 basic components: "awareness, people knowing about problems related to health, health risks, and ways to solve this problem; formation of personal attitude towards a certain problem; changes in behavior" [27]. So, there are several basic theories which can be applied when we analyze influence exerted by communication programs and projects. Communication programs efficiency is often analyzed only within medical statistics 
frameworks. And here we should note that sociological research plays a significant role in analyzing communication about health because it helps to examine changes in people's knowledge and motivation, their satisfaction with information they get, as well as to be more precise in determining essence of changes in behavioral strategies, and how committed people are to health preserving behavior.

So, we can state that communication about health is a scientific branch which is being institutionalized at the moment. Its theoretical aspects are built on scientific postulates developed in communication sociology, health sociology, and medical sciences. There are several basic theoretical models which consider functioning of communication about health. They focus on analysis of communication participants, such as medical experts, specialists in healthcare, authorities, mass media, public organizations, and population, who receive information which should help them reduce their risky behavior as regards their own health. Communication about health can be considered at several levels: interpersonal (a doctor and a patient), group, organizational, and mass one. Occurring interactions are examined by scientists within a wide social context (political and economic situation, public healthcare functioning) and are seen as a social institute, as people's behavioral practices that exist in this particular society. Special attention during communication analysis is paid to theoretical understanding how communication influences people's awareness, attitudes, and behavior; it allows to apply such classic theories of changes as the theory of planned behavior, the theory of "belief in health", and theory of stage changes in behavior when we analyze communication about health.
Communication about health in its practical aspect is realized via communication programs which are aimed at raising population awareness and reducing health risks. Such communication programs are widely spread in the USA and Western Europe and are most frequently implemented within electronic healthcare, mobile healthcare, or telemedicine. There are a lot of prevention programs existing in the RF at the moment; their main task is to reduce risky behavior as regards people's health. Experts perform various research aimed at assessing and analyzing existing health risks. However, we can state that mass communication media have a significant potential which is not fully realized in terms of its possible application in order to exert complex influence on population. There are some unsystematic initiatives to implement mobile and electronic healthcare programs. Efficiency of such programs should be assessed not only within medical statistics frameworks, but also with sociological techniques application which will help to reveal what influence was exerted by this or that program on health and social relationships as a whole.

To conclude, we can state that it is quite promising both to get better theoretical insight into communication about health and to implement information and communication programs. When such a complicated phenomenon as communication in the sphere related to health is examined, both medical experts and specialists in social and humanitarian sciences should combine their efforts.

Funding. Our research was not granted any sponsors' support.

A conflict of interests. The authors state there is no conflict of interests. 


\section{References}

1. Chislo umershikh po osnovnym klassam prichin smerti [Number of death cases as per basic death causes]. Federal'naya sluzhba gosudarstvennoi statistiki: ofitsial'nyi sait. Available at: http://www.gks.ru/free doc/ new_site/population/demo/demo24.xls (06.06.2018) (in Russian).

2. Neinfektsionnye zabolevaniya [Non-infectious diseases]. Vsemirnaya organizatsiya zdravookhraneniya: ofitsial'nyi sait. Available at: http://www.who.int/ru/news-room/factsheets/detail/noncommunicable-diseases (02.06.2018) (in Russian).

3. National Cancer Institute. Making Health Communications Programs Work. Washington DC, National Institutes of Health Publ., 2008, 19 p.

4. Tyukhlova I.N., Prot'ko N.N. Sovremennye podkhody k organizatsii sanitarnogo prosveshcheniya naseleniya [Contemporary approaches to sanitary education of population]. Aktual'nye problemy meditsiny: materialy nauchno-prakticheskoi konferentsii, posvyashchennoi 55-letiyu uchrezhdeniya obrazovaniya "Grodnenskii gosudarstvennyi meditsinskii universitet» (3-4 oktyabrya 2013 g.): v 2 ch. In: V.A. Snezhitskii ed. Grodno, GrGMU publ., 2013, part. 2, pp. 325 (in Russian).

5. Graduate Programs in Health Education and Communication. GradSchools.com. Available at: https://www.

gradschools.com/programs/public-health/health-education-communication (06.06.2018).

6. Barg A.O. Risk-kommunikatsiya v sfere zdorov'ya kak vid sotsial'noi kommunikatsii [Risk-communication in the sphere of health as a sort of social communication]. Diskussiya, 2017, vol. 75, no. 1, pp. 50-55 (in Russian).

7. Handbook of health communication. In: T.L. Thompson, A. Dorsey, K. Miller eds. Mahwah, NJ, Lawrence Erlbaum Associates Publ., 2003, pp. 47-53.

8. Wiener N. Cybernetics. New York, John Wiley, 1948, 19 p.

9. Kuz'min K.V., Semenova E.V., Petrova L.E., Zakroeva A.G. Kommunikatsiya vracha i patsienta: proshloe, nastoyashchee, budushchee [Communications between a doctor and a patients: past. present, and future]. Ekaterinburg, Izdatel'stvo UGMU Publ., 2016, pp. 119-130 (in Russian).

10. Nazarova I.B. Vzaimootnosheniya vrach-patsient: pravovye i sotsial'nye aspekty ["Doctor-patient" interrelation. Legal and social aspects]. Sotsiologicheskie issledovaniya, 2004, no. 7, pp. 142-147 (in Russian).

11. Elektronnoe zdravookhranenie v Evropeiskom regione [Electronic health care in Europe]. Vsemirnaya organizatsiya zdravookhraneniya: ofitsial'nyi sait. Available at: http://www.euro.who.int/ru/health-topics/Health-systems/e-health (06.06.2018) (in Russian).

12. Tarasenko E.A. Patient 2.0: kommunikatsii patsientov i vrachei v sotsial'nykh setyakh [Patient 2.0: communications between patients and doctors in social networks]. XIII Mezhdunarodnaya nauchnaya konferentsiya po problemam razvitiya ekonomiki i obshchestva. In: E.G. Yasin ed. Moscow, Izdatel'skii dom NIU VShE Publ., 2012, part 3, pp. 204 (in Russian).

13. Dmitrieva E.V. Sotsiologiya zdorov'ya: metodologicheskie podkhody i kommunikatsionnye programmy [Sociology of health: methodological approaches and communication programs]. Moscow, Izd-vo Tsentr publ., 2002, pp. 184-190 (in Russian).

14. Brewin T. Truth, trust and paternalism. Health and disease. In: B. Davey, A. Gray eds. Buckingham Philadelphia, Open University Press Publ., 1995, pp. 327-331.

15. Yakovleva I.V. Kommunikatsiya $\mathrm{v}$ sfere zdravookhraneniya: upravlencheskii aspekt [Communications in Healthcare: The Administrative Aspect]. Gosudarstvennoe upravlenie. Elektronnyi vestnik, 2016, no. 59, pp.168-188 (in Russian). 
16. Zaitseva N.V., Barg A.O. Risk-kommunikatsiya kak instrument upravleniya vospriyatiem riskov zdorov'yu naseleniya, svyazannykh $\mathrm{s}$ zagryazneniem sredy obitaniya [Riskcommunication as an instrument of health risk perception management]. Zdorov'e sem'i - 21 vek, 2014, no. 4, pp. 36-48 (in Russian).

17. Barg A.O., Lebedeva-Nesevrya N.A. Risk-kommunikatsiya kak mekhanizm formirovaniya adekvatnoi otsenki riskov dlya zdorov'ya naseleniya [Risk-communication as an effective way of producing the cumulative acceptability of human health risks]. Zdorov'e naseleniya i sreda obitaniya, 2014, vol. 261, no. 12, pp. 9-11 (in Russian).

18. Healthy People 2010 Final Review. Centers for Disease Control and Prevention: National Center for Health Statistics. Available at: https://www.cdc.gov/nchs/healthy people/hp2010/hp2010 final review.htm (06.06.2018).

19. Health communication campaigns. Centers for decease control and prevention. Available at: https:// www.cdc.gov/healthcommunication/campaigns/index.html (06.06.2018).

20. Barg A.O., Lebedeva-Nesevrya N.A. Risk-kommunikatsiya v sisteme analiza professional'nykh riskov zdorov'yu rabotnikov promyshlennogo predpriyatiya [Risk communication in analysis of occupational health risk for industrial workers]. Meditsina truda i promyshlennaya ekologiya, 2015, no. 8, pp. 28-33 (in Russian).

21. Natsional'nyi monitoring zdorov'ya rossiyan [National monitoring over population health in Russia]. Vserossiiskii tsentr izucheniya obshchestvennogo mneniya: ofitsial'nyi sait. Available at: https://wciom.ru/index.php?id=236\&uid=922 (10.06.2018) (in Russian).

22. Kommunikatsionnye programmy [Communication programs]. Zdorov'e i razvitie: ofitsial'nyi sait fonda. Available at: http://www.fzr.ru/programs.html (06.06.2018) (in Russian).

23. Rimal R.N., Lapinski M.K. Why health communication is important in public health. Bulletin of the World Health Organization, 2009, vol. 87, pp. 247-247. DOI: 10.2471/BLT.08.056713. Available at: http:// www.who.int/bulletin/volumes/87/4/08-056713/en/ (07.06.2018).

24. Vizgalov D.V. Metody otsenki munitsipal'nykh program [Techniques for municipal programs assessment]. Moscow, Fond «Institut ekonomiki goroda» publ., 2004, 108 p. (in Russian).

25. Corcoran N. Theories and models in communicating health messages. London, Sage Publications publ., 2007, pp. 15-21.

26. Ajzen Icek The theory of planned behavior. Organizational Behavior and Human Decision Processes, 1991, vol. 50, no. 2, pp. 179-211.

27. Averin Yu.P., Dmitrieva E.V. Sotsiologicheskie issledovaniya: mesto i rol' v kommunikativnykh kampaniyakh, metodologiya i metodika provedeniya [Sociological research: their role in communication campaigns, methodology and techniques of their conducting]. Moscow, Fond «Zdorovaya Rossiya» publ., 2006, pp. 46 (in Russian).

Grishina M.A. Health communication: theoretical and practical aspects. Health Risk Analysis, 2018, no. 2, pp. 138-150. DOI: 10.21668/health.risk/2018.2.16.eng

Received: 31.05 .2018

Accepted: 15.06.2018

Published: 30.06.2018 